\title{
Effect of Crocin on Letrozole-Induced Polycystic Ovarian Syndrome
}

\author{
YASMIN M. EID, M.Sc.; ELHAM M. NASIF, M.D.; MOHAMMED M. SHEBL, M.D. and \\ MOHAMMED M. MADI, M.D. \\ The Department of Physiology, Faculty of Medicine, Tanta University, Tanta, Egypt
}

\begin{abstract}
Background: Letrozole (LET), a non steroidal aromatase inhibitor. Produce an animal model to study Polycystic Ovarian Syndrome (PCOS). Clomiphene Citrate (CC), first-line in treatment of PCOS. Crocin is a carotenoid used as traditional medicine to treat many diseases.

Aim of Study: Study effect of crocin on letrozole-induced polycystic ovarian syndrome.

Material and Methods: Forty local strainfemale rats were used in this study; these animals were divided into four main groups (ten rats each). Group I: Normal group.

Group II (Letrozole-induced PCOS group): These animalswere adminstred LET once daily in a dose of $1 \mathrm{mg} / \mathrm{kg}$ for 21 consecutive days by oral gavage. Group III; Crocin-treated group: Received LET as group II, then crocin $50 \mathrm{mg} / \mathrm{Kg}$ once daily by intraperitoneal injection for 6 weeks. Group IV (CC treated group): Received LET as in group II, then CC $1 \mathrm{mg} / \mathrm{kg}$ once daily by oral gavage for 6 weeks. Blood samples were collected by cardiac puncturefor analysis ofserumtestosterone. FSH, LH, estradiol, glucose, insulin and total cholesterol. HOM-IR where calculated. Ovaries were be dissected out. One ovary from one animal of each group was preserved in $10 \%$ formalin for histopathological study.
\end{abstract}

Results: Letrozole treatment resulted in, increase in serum testesterone, FSH, LH, glucose, insulin, cholesterol levels and also, decrease in serum estradiol level. However, after injection of crocin, all parameters studied returned back to nearly normal levels as in control group there were no changes between crocin treated or CC treated groups. These results were confirmed by histopathological examination.

Conclusion: These findings highlighted the important role played by crocin in treatment of polycystic ovarian syndrome.

Key Words: Polycystic ovarian syndrome - Crocin-Clomiphene citrate.

\section{Introduction}

POLYCYSTIC Ovarian Syndrome (PCOS) is recognized as the most common endocrinopathy

Correspondence to: Dr. Yasmin M. Eid,

E-Mail: jasmineid011@gmail.com of women. The causes of PCOS are not fully understood [1] and its management is often unsatisfactory or requires a diversified approach.

Letrozole (LET), a non steroidal aromatase inhibitor, produces an animal modelto study PCOS. This animal model in several ways is similar to the human polycystic ovary syndrome [2] .

Clomiphene citrate (CC) is considered as firstline in treatment of PCOS women [3]. It works by blocking estrogen receptors at the hypothalamus which is stimulated to release follicle stimulating hormoneand luteinizing hormone.

Nowadays people are focusing towards allopathic medicines to get the temporary relief for many diseases. However, women with PCOS can find alternative therapy for permanent cure. Herbal medicines are the most popular alternative therapy among all [1].

Crocin is a carotenoidobtained commercially from the dried trifid stigma of the culinary spice crocus sativus L. (saffron) and is responsible for the red color of saffron. It is used as a traditional medicine, throughout history [4].

The aim of the present work is to study effect of crocin on letrozole-induced polycystic ovarian syndrome.

\section{Material and Methods}

Drugs: Crocin was obtained from Sigma Aldrish as a powder and dissolved by addition of normal saline. Letrozlewas obtained from Novartis and dissolved by addition of normal saline.

Experimental animals: The present work was carried out on 40 female adult rats of local strain 
weighing (180-200gm). These rats were housed in isolated animal cages, ten in each cage, in a standard animal laboratory room in Faculty of Medicine, Tanta University during 2018 and had free access to water and food ad libtiumall over the period of the work, and were kept at room temperature. Rats were acclimatized to the new environment for 7 days prior to the start of the experiments. All procedures were done according to the instructions of the ethical committee of Tanta University.

\section{Experimental design and animal grouping:}

The animals were divided into four groups (10 rats for each):

1- Group I: (Normal control group): The animals of this group received $0.5 \mathrm{ml}$ saline daily by intraperitoneal injection (IP) and $0.5 \mathrm{ml}$ saline by oral gavage for 21 days.

2- Group II: (LET-induced PCOS group): The animals of this group received LET once daily in a dose of $1 \mathrm{mg} / \mathrm{kg}$ for 21 consecutive days by oral gavage to induce PCOS [5]

3- Group III: (Crocin-treated group):The animals of this group received LET as group II to induce PCOS, then crocin $50 \mathrm{mg} / \mathrm{Kg}$ once daily by (IP) injection for 6 weeks [6].

4- Group IV: (CC-treatedgroup): The animals of this group received LET as group II to induce PCOS then, CC $1 \mathrm{mg} / \mathrm{kg}$ once daily by oral gavage for 6 weeks [7]

\section{Blood and tissue sampling:}

At the end of experimental period, all animals were fasted for 12 hour, deeply anesthetized by diethyl ether, then sacrificed by cervical decapitation and blood samples were collected.

Ovaries were dissected out, one ovary from one rat in each group.

\section{Biochemical analysis:}

Free serum testosterone [8], estradiol [9], FSH [10], LH [11], fasting glucose [12] and insulin [13] levels were measured. Insulin resistance (HOMA IR\%) was also calculated [14]. Serum total cholesterol level, was measured by BioMed-cholesterolLS kits [12].

\section{Histopathological study:}

Ovaries were fixed in Bouin's fixative then subsequently washed and stored in $10 \%$ formalin until processing and embedding in paraffin wax. After embedding, each ovary was serially sectioned at the diagonal plane at 4 ickness and subsequently stained with hematoxylin and eosin [15] using standard techniques for histopathological examination.

\section{Statistical analysis:}

Data were analyzed using Statistical Program for Social Science (SPSS) version 17 using one way Analysis of Variance (ANOVA) followed by Tukey-Kramer multiple test for comparison between individual groups. Data were expressed as mean + Standard Deviation (SD) [16]

\section{Results}

The results of this work showed that LET administration caused significant increase in all studied parameters except serum estradiol which showed significant decrease compared to control group ( $p \leq 0.05)$. Treatment of animals with crocin or CC resulted in decrease in all studied parameters except serum estradiol level which showed significant increase when compared to LET-induced PCOS group $(p \leq 0.05)$. There was no change in studied parameters in both crocin-treated and CCtreated groups when compared to control group $(p \geq 0.05)$ (Tables 1,2$)$.

Table (1): Serum free testosterone (ng/ml) estradiol (pg/ml) FSH (mlu/ml) LH (mlu/ml), in all studied groups (mean values $\pm \mathrm{SD}$ ).

\begin{tabular}{llcccc}
\hline \multicolumn{1}{c}{ Groups } & \multicolumn{1}{c}{ G1 } & $\begin{array}{c}\text { GII } \\
\text { Colycyctic } \\
\text { Parameters }\end{array}$ & $\begin{array}{c}\text { GIII } \\
\text { Crocin } \\
\text { treated }\end{array}$ & $\begin{array}{c}\text { GIV } \\
\text { clomiphene } \\
\text { citrate treated }\end{array}$ & F \\
\hline Serum free testosterone level $(\mathrm{ng} / \mathrm{ml})$ & $2.41 \pm 0.12$ & $4.16^{*} \pm 0.47$ & $2.44 \# \pm 0.13$ & $2.44 \# \pm 0.13$ & 109.651 \\
Serum estradiol level $(\mathrm{pg} / \mathrm{ml})$ & $90.48 \pm 1.09$ & $81.40^{*} \pm 0.80$ & $90.32 \# \pm 1.10$ & $90.05 \# \pm 0.79$ & 216.425 \\
Serum FSH level $(\mathrm{mlu} / \mathrm{ml})$ & $0.04 \pm 0.01$ & $0.12 * \pm 0.03$ & $0.05 \# \pm 0.02$ & $0.05 \# \pm 0.02$ & 24.840 \\
Serum LH level $(\mathrm{mlu} / \mathrm{ml})$ & $0.27 \pm 0.04$ & $0.47 * \pm 0.02$ & $0.28 \# \pm 0.05$ & $0.28 \# \pm 0.04$ & 67.333 \\
\hline
\end{tabular}

*: Denotes statistical significance $(p \leq 0.05)$ compared with the control group.

\#: Denotes statistical significant $(p \leq 0.05)$ compared with the PCOS group. 
Table (2): Serum glucose (mg/dl), insulin ( $\mathbf{I} / \mathrm{m})$, HOMA IR cholesterol (mg/dl) in all studied groups (mean values $\pm \mathrm{SD}$ ).

\begin{tabular}{llllll}
\hline \multicolumn{1}{c}{ Groups } & \multicolumn{1}{c}{$\begin{array}{c}\text { G1 } \\
\text { Control } \\
\text { group }\end{array}$} & $\begin{array}{c}\text { GII } \\
\text { polycyctic } \\
\text { ovary group }\end{array}$ & $\begin{array}{c}\text { Crocin treated } \\
\text { group }\end{array}$ & $\begin{array}{c}\text { GIV } \\
\text { clomiphene } \\
\text { citrate treated group }\end{array}$ & F \\
\hline Serum glucose $(\mathrm{mg} / \mathrm{dl})$ & $91.25 \pm 9.98$ & $196.22^{*} \pm 12.24$ & $91.32 \# \pm 9.94$ & $92.88 \# \pm 10.03$ & 173.908 \\
Insulin level $(\mu \mathrm{IU} / \mathrm{ml})$ & $12.70 \pm 2.26$ & $21.55^{*} \pm 2.23$ & $12.38 \# \pm 1.9$ & $13.68 \# \pm 2.01$ & 42.083 \\
HOMA IR & $2.81 \pm 0.23$ & $10.43^{*} \pm 1.1$ & $2.83 \# \pm 0.16$ & $3.00 \# \pm 0.26$ & 152.032 \\
Serum cholesterol $(\mathrm{mg} / \mathrm{dl})$ & $118.91 \pm 15.4$ & $144.42 * \pm 14.78$ & $119.45 \# \pm 13.95$ & $120.07 \# \pm 15.01$ & 7.122 \\
\hline
\end{tabular}

*: Denotes statistical significance $(p \leq 0.05)$ compared with the control group.

\#: Denotes statistical significant $(p \leq 0.05)$ compared with the PCOS group.

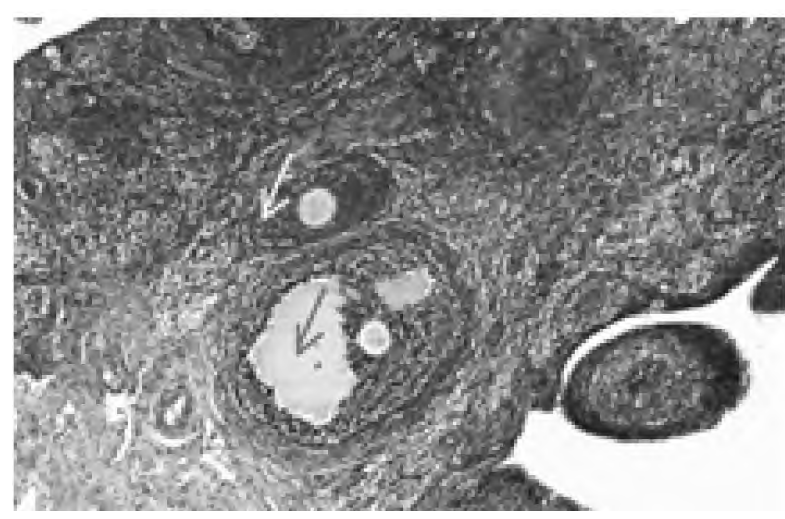

Fig. (1): Control group, normal ovarian structure showing primary folllicle (yellow arrow) and Graafian follicle (red arrow) under the surface epithelium $(\mathrm{H} \& \mathrm{E}$ 100).

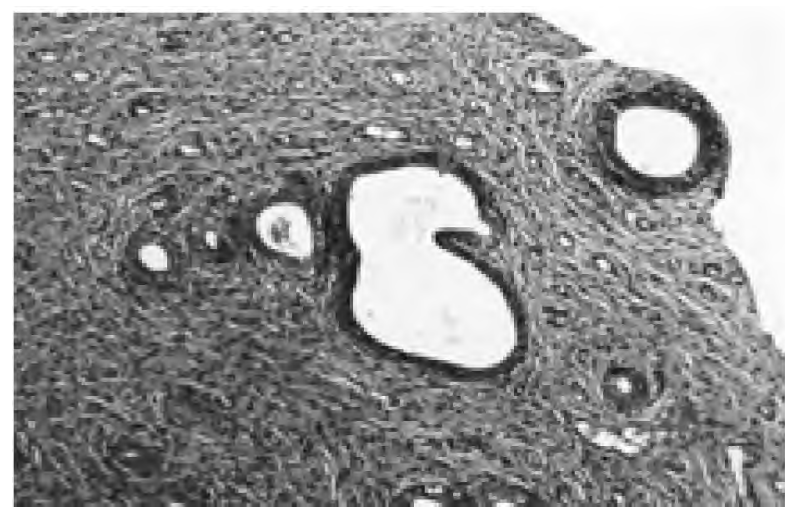

Fig. (2): PCO, section in the ovary showing multiple cystically dilated follicles (red arrow) (H \& E 200).

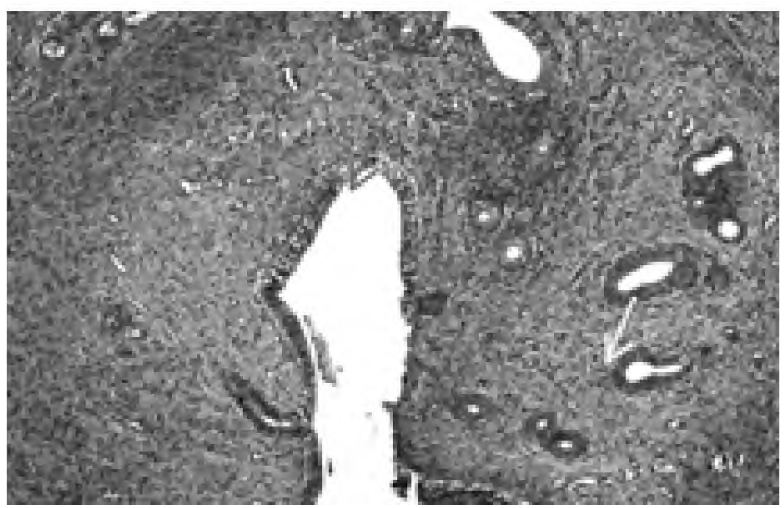

Fig. (3): PCO, section in the ovary showing a large cystically dilated follicle (red arrow) and multiple small cystic follicles (yellow arrow) (H \& E 100).

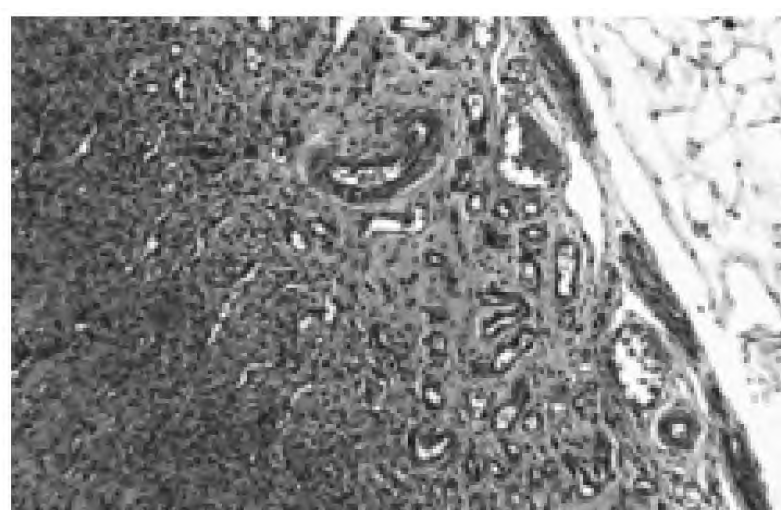

Fig. (4): Crocin treated group, section in the ovary showing no cystic changes with many blood vessels (red arrow) in the medulla (H \& E 200).

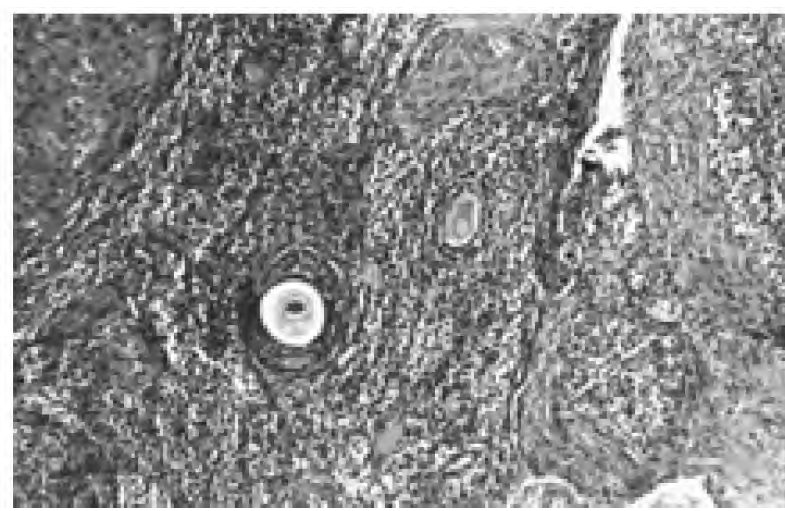

Fig. (5): CC treated group, section in the ovary showing normal ovarian structure with ovarian follicles (red arrow) and no cystic changes (H \& E 200).

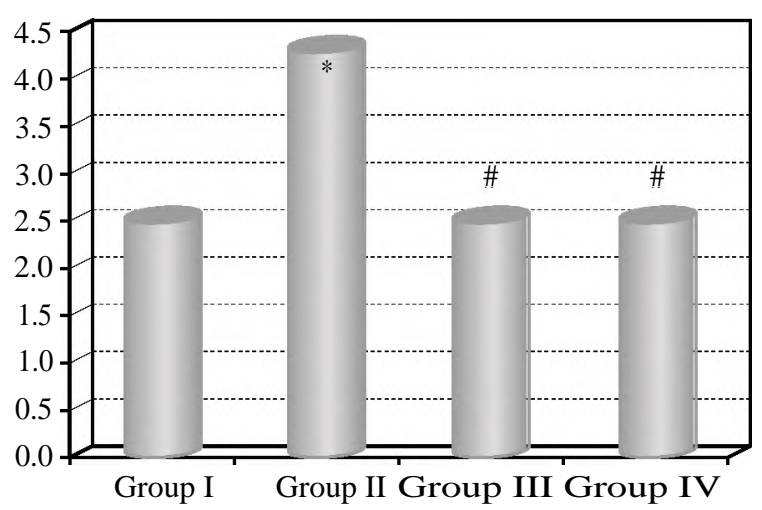

Fig. (6): Serum free testosterone level $\mathrm{ng} / \mathrm{ml}$ in all studied groups. 


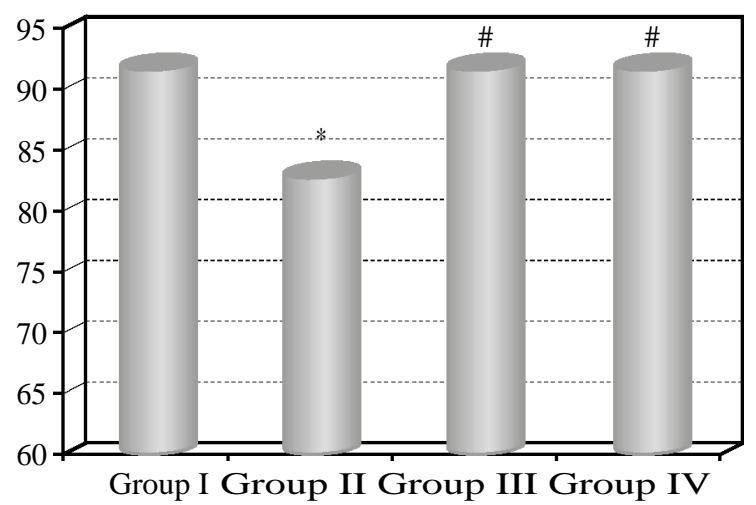

Fig. (7): Serum estradiol level $\mathrm{pg} / \mathrm{ml}$ in all studied groups.

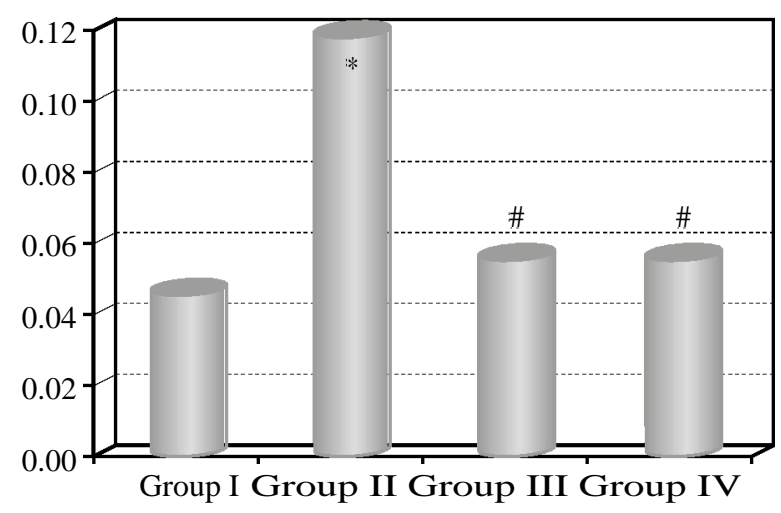

Fig. (8): Serum FSH level $(\mathrm{mlu} / \mathrm{ml})$ in all studied groups.

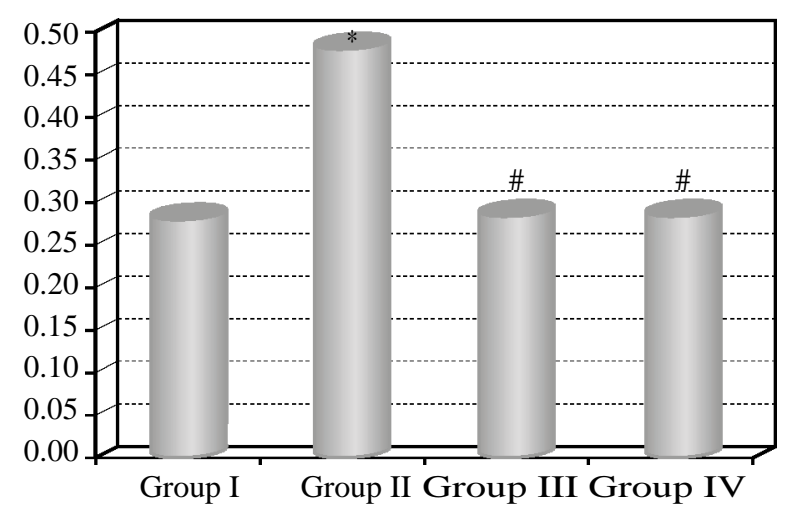

Fig. (9): Serum LH level (mlu/ml) in all studied groups.

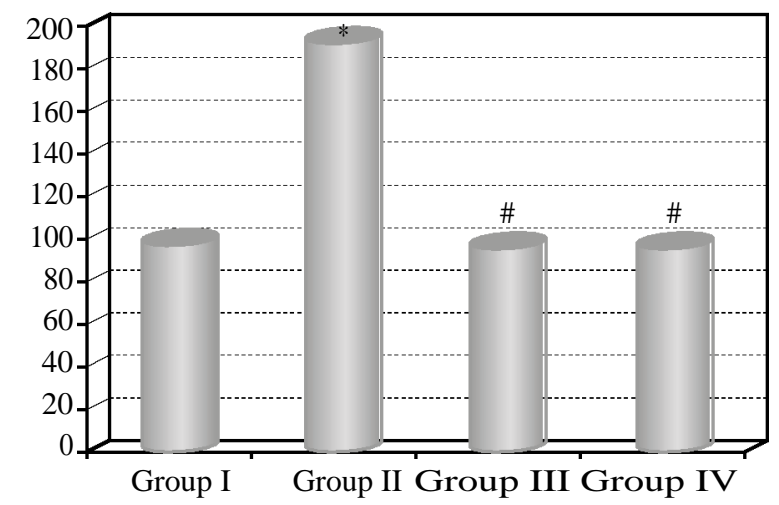

Fig. (10): Serum glucose level (mg/dl) in all studied groups.

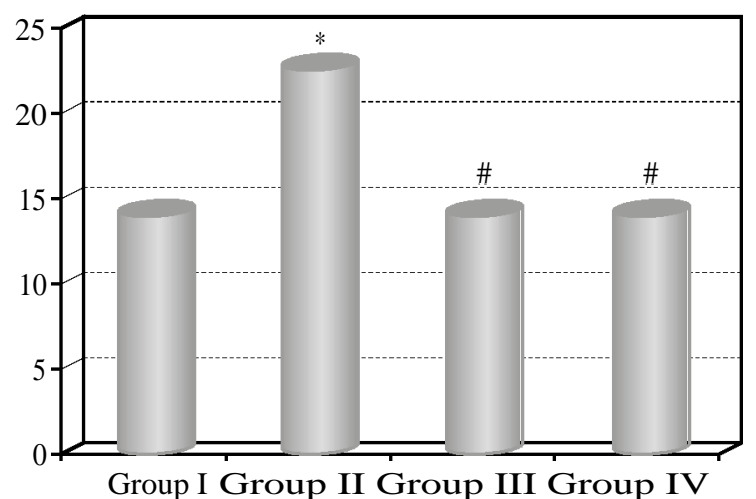

Fig. (11): Serum insulin level (

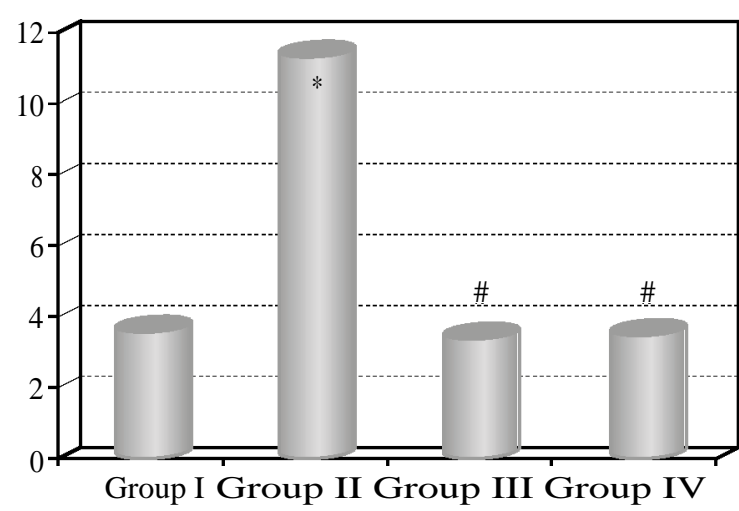

Fig. (12): HOMA IR value in all studied groups.

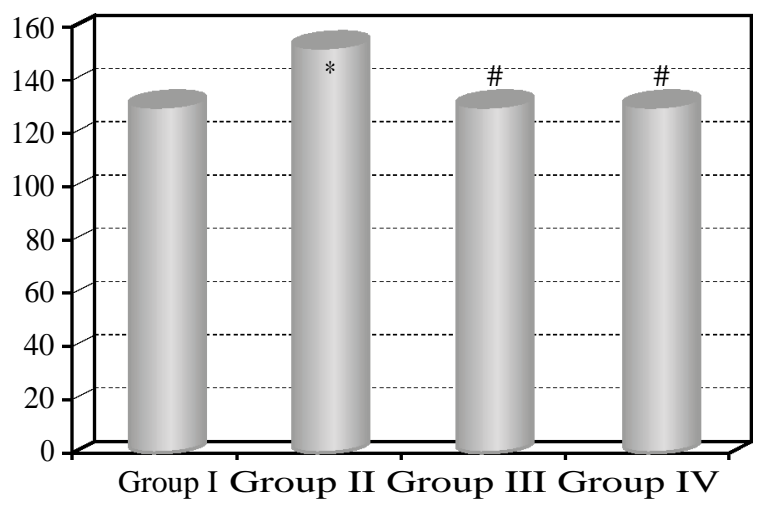

Fig. (13): Serum cholesterol level (mg/dl) in all studied groups.

\section{Discussion}

The results of the present study showed that in letrozole-induced PCOS group, there was significant increase in serum free testosterone, $\mathrm{LH}$ and serum FSH level. On the other hand serum estradiol level showed significant decrease compared to control group.

Pandey et al., further supports the role of oxidative/nitro sative stress in the pathogenesis of letrozole-induced hyperandrogenic and hormonal changes in PCO rats [17]. The mechanism by which letrozole non-steroidal aromatase inhibitor produces 
these changes in the hormonal profile could be explained by altering reproductive gene expression at multiple levels of the hypothalamic-pituitarygonadal axis [18]. The significant increase in testosterone and decrease in estradiol could be also explained by blocking conversion of testosterone and androstenedione to estradiol and estrone respectively [19]. This decreases the estrogenic activity releasing the hypothalamus from its negative feedback leading to an increase in FSH release [20]. The hypothalamus becomes hyperactive in PCOs and secrets gonadotropins releasing hormone $(\mathrm{GnRH})$ more often than usual without identified reason that leads to excess production of Luteinizing Hormone (LH) and Follicle Stimulating Hormone (FSH) [18].

Steroidogenic enzymes are required for formation of active sex steroids asdihydrotestosterone (DHT) and the estrogens 170 -estradiol $\left(\mathrm{E}_{2}\right)$. In PCOS, estrogen synthesis isinhibited by the use of LET the 30 HSD activity is higher compared to 170 HSD activity, and androgen production will be higher than estrogen production with a secondary change LH: FSH hormonal balance [21]

$\mathrm{CC}$ is an anti-estrogen it works by blocking estrogen receptors at the hypothalamus which is stimulated to release Follicle Stimulating Hormone (FSH) and luteinizing hormone [22] .

Crocin administration caused significant decrease in serum free testosterone level, FSH level, LH level and significant increase in serum estradiol level in letrezole induced PCOS. Treatment with clomiphene citrate to PCO rats induced by letrozole resulted in the same changes caused by treatment with crocin.

Crocin may reduce hypophysis-hypothalamus sensitivity to testosterone and subsequently the negative feedback control on Luteinizing Hormone $(\mathrm{LH})$ secretion [23]. Another cause for the therapeutic effect of crocin is demonstrated by Sajjadi and Bathaie, who observed that growth in basophil cellsof the anterior pituitary which responsible for LH and FSH production [24] . Krsmanovic et al., also showed that crocin is capable of releasing $\mathrm{LH}$ hormone by affecting hypothalamus axis and increasing the secretion rate of GnRH hormone [25] Zohrabi et al., observed that crocin reduces plasma levels of total cholesterol therefore, the reduced estrogen level reported in the present study could be due to a reduction in cholesterol levels [26]

It was evident from results of the present work that LET administration to female rats caused significant increase in serum glucose level, serum insulin level and HOMA IR. The hyperglycemia and hyperinsulinemia secondary to insulin resistance in LET induced PCOS animals, the significant elevation of androgen levels in LET treated groups are partly responsible for insulin resistance [27] Another mechanism for insulin resistance may be chronic low-grade inflammation which emerged as a key contributor to the pathogenesis of Polycystic Ovary Syndrome (PCOS). The pro-inflammatory cytokine tumor necrosis factor- a (TNF$(\mathrm{x})$ is a known mediator of insulin resistance [28] Another cause of insulin resistance in letrozol induced PCOS is the paracrine dysregulation of adipokine (for example, adiponectin) production by macrophage-secreted cytokines in PCOS favors development of insulin resistance [29], plasma leptin levels were higher in letrozole treated rats than in controls Hyperleptinemia is thought to indicate leptin resistance, which may be strongly connected to insulin resistance [30].

Results of the present work reveal that LET administration to rats resulted in significant increase in serum cholesterol level. Thiscould explained by the aromatase inhibitors, LET may interfere with enzymatic pathways in the liver or with bile acid secretion [31]. The significantly decreased serum cholesterol as a result to crocin administration to LET induced polycystic ovary animal could explained by competitive inhibiton of pancreatic lipase. Leading to the malabsorption of cholesterol [32]. Clomiphene citrate treatment in polycystic ovary female rats causes also improvement of serum cholesterol, which may be attributed to the estrogenic biological activities of clomiphene citrate [33]

Histopathological data reveals that LET induced PCOS. It showed numerous subcapsular cysts, with no granulosa layer. Corpora lutea were completely absent indicating anovulation. In addition, they were accompanied with atretic follicles containing fluid filled antrum and higher incidence of pyknotic granulosa cells. These signs were ameliorated after crocin treatment.

\section{Conclusion:}

These findings highlight the important role played by crocin in treatment of polycystic ovarian syndrome.

Further studies in different species, including man, are necessary to clarify the role of the crocin in pathophysiology in those people suffering from polycystic ovarian syndrome.

Conflict of interest statement: Authors declare no conflict of interest. 


\section{References}

1- DHIVYA C.V. and DERERA P.: Role of herbals in the management of polycystic ovarian syndrome and its associated symptoms. International Journal of Herbal Medicine, 5 (5): 125-31, 2017.

2. MALIQUEO M., SUN M., JOHANSSON J., BENRICK A., LABRIE F., et al.: Continuous administration of a P450 aromatase inhibitor induces polycystic ovary syndrome with a metabolic and endocrine phenotype in female rats at adult age. Endocrinology, 154: 434-45, 2013.

3- HOMBURG R.: Management of infertility and prevention of ovarian hyperstimulation in women with polycystic ovary syndrome. Best Pract. Res. Clin. Obstet. Gynaecol., 18 (5): 773-88, 2004.

4- ASADI M.H., ZAFARI F., SARVEAZAD A., ABBASI M., SAFA M., et al.: Saffron improves epididymal sperm parameters in rats exposed to cadmium. Nephrourol. Mon., 6 (1): e12125, 2014.

5- Di PIETRO M., PARBORELL F. and IRUSTA G.: Metformin regulates ovarian angiogenesis and follicular development in a female polycystic ovary syndrome rat model. Endocrinology, 156: 1453-63, 2015.

6- KIANBAKHT S. and HAJIAGHAEE R.: Anti-hyperglycemic effects of saffron and its active constituents, crocin and safranal, in alloxan-induced diabetic rats. J. Med. Plants., 10 (39): 83-9, 2011.

7- TABARAK I.M.H., AHMED G., JAHAN N. and ADEEBA M.: Physicochemical standardization of Tukhmekarafs seeds of Apiumgraveolens Linn. IJCP, 06: 1-6, 2013.

8- MORLEY J.E., PATRICK P. and PERRY H.M.: Evaluation of assays available to measure free testosterone. Metabolism, 51 (5): 554-9, 2002.

9- CANPOLAT S., TUG N., SEYRAN A.D., KUMRU S. and YILMAZ B.: Effects of raloxifene and estradiol on bone turnover parameters in intact and ovariectomized rats. J. Physiol. Biochem., 66: 23-8, 2010.

10- AY V.L., MIDGLEY A.R. and NISWENDER G.D.: Patterns of gonadotropin secretion associated with ovulation. Fed. Proc., 29: 1880-7, 1970.

11- HAAVISTO A.M., PETTERSSON K., BERGENDAHL M., PERHEENTUPA A., ROSER J.F., et al.: A supersensitive immunofluorometric assay for rat luteinizing hormone. Endocrinology, 132 (4): 1687-91, 1993.

12- Tietz N.W.: Fundamentals of Clinical Chemistry WB Saunders. Philadelphia, Pp. 322-60, 1976.

13- KAO P.C., TAYLOR R.L. and SERVICE F.J.: Proinsulin by Immunochemiluminometric Assay for the Diagnosis of Insulinoma. J. Clin. Endocrinol. Metab., 78 (5): 104851, 1994.

14- VOGESER M., KÖNIG D., FREY I., PREDEL H.G., PARHOFER K.G., et al.: Fasting serum insulin and the homeostasis model of insulin resistance (HOMA-IR) in the monitoring of lifestyle interventions in obese persons. Clin. Biochem., 40 (13-14): 964-8, 2007.

15- REDDY P.S., BEGUM N., MUTHA S. and BAKSH V.: Beneficial effect of Curcumin in Letrozole induced polycystic ovary syndrome. Asian Pacific Journal of Reproduction, 5 (2): 116-22, 2016.
16- INDRAYAN A. and SARMAUKADDAM S.B.: Medical Biostatics 1 st Ed. Marcel-Dekker, Delhi, India P50, 2001.

17- PANDEY V., SINGH A., SINGH A., KRISHNA A., PANDEY U., et al.: Role of oxidative stress and lowgrade inflammation in letrozole-induced polycystic ovary syndrome in the rat. Reprod Biol., 16 (1): 70-7, 2016.

18- KAUFFMAN A.S., HACKRAY V.G., RYAN G.E., TOLSON K.P., GLIDEWELL-KENNEY C.A., et al.: A Novel Letrozole Model Recapitulates Both the Reproductive and Metabolic Phenotypes of Polycystic Ovary Syndrome in Female Mice. Biology of Reproduction, 93 (3): 1-12, 2015.

19- EAGLESON C.A., GINGRICH M.B., PASTOR C.L., ARORA T.K., BURT C.M., et al.: Polycystic ovarian syndrome: Evidence that flutamide restores sensitivity of the gonadotropin-releasing hormone pulse generator to inhibition by estradiol and progesterone. J. Clin. Endocrinol. Metab, 85: 4047-52, 2000.

20- FAUSER B.C., TARLATZIS B.C., REBAR R.W., LEGRO R.S., BALEN A.H., et al.: Consensus on women's health aspects of polycystic ovary syndrome (PCOS): The Amsterdam ESHRE/ASRM-Sponsored 3 rd PCOS Consensus Workshop Group. Fertil Steril., 97: 28-38, 2012.

21- MEYER K., MARTINO-ANDRADE A.J., SANTOS A.D and De MORAIS R.N.: Domestic cat testicular aromatase activity as assessed by the tritiated water-release assay. Anim. Reprod., 11 (4): 549-56, 2014.

22- CASPER R.F.: Letrozole versus clomiphene citrate: Which is better for ovulation induction? Fertil Steril., 92 (3): 858-9, 2009.

23- VASEGH M., KOOHPEYMA F., JAHROMI H.K., BATHAEE S.H., SABERI R., et al.: Investigating effects of hydroalcoholic extract of saffron on sex hormones in female rats undergoing chemotherapy with cyclophosphamide Comparative Clinical Pathology, 24 (2): 399-402, 2015.

24- SAJJADI M. and BATHAIE Z.: Comparative study on the preventive effect of saffron carotenoids, crocin and crocetin, in nmu-induced breast cancer in rats. Cell J., 19 (1): 94-101, 2017.

25- KRSMANOVIC L.Z., HU L., LEUNG P.K., FENG H. and CATT K.J.: The hypothalamic GnRH pulse generator: Multiple regulatory mechanisms. Trends. Endocrinol. Metab., 20 (8): 402-8, 2009.

26- ZOHRABI D., PARIVAR K., SANATI M.H. and HAYATIROODBARI N.: Effects of crocin on the pituitarygonadal axis and hypothalamic kiss- 1 gene expression in female wistar rats. Int. J. Fertil Steril., 12 (1): 56-60, 2018.

27- FAULDS G., RYDÉN M., EK I., WAHRENBERG H. and ARNER P.: Mechanisms behind lipolytic catecholamine resistance of subcutaneous fat cells in the polycystic ovarian syndrome. J. Clin. Endocrinol. Metab., 88 (5): 2269-73, 2003.

28- GONZÁLEZ F.: Inflammation in Polycystic Ovary Syndrome: Underpinning of insulin resistance and ovarian dysfunction. Steroids, 77 (4): 300-5, 2012.

29- CHAZENBALK G., TRIVAX B.S., YILDIZ B.O., BERTOLOTTO C., MATHUR R., et al.: Regulation of adi- 
ponectin secretion by adipocytes in the polycystic ovary syndrome: Role of tumor necrosis factor- $\{$ alpha $\}$. J. Clin. Endocrinol. Metab., 95 (2): 935-42, 2010.

30- MANNERÅS L., CAJANDER S., HOLMÄNG A., SELESKOVIC Z., LYSTIG T., et al.: A new rat model exhibiting both ovarian and metabolic characteristics of polycystic ovary syndrome. Endocrinology, 148 (8): 3781 91, 2007.

31- ELISAF M.S., BAIRAKTARI E. T., NICOLAIDES C., KAKAIDI B., TZALLAS C.S., et al.: Effect of letrozole on the lipid profile in postmenopausal women with breast cancer European Journal of Cancer, 37 (12): 1510-3, 2001.

32- THUSHARA R.M., HEMSHEKHAR M., SANTHOSH M.S., DEVARAJA S., KEMPARAJU K., et al.: Differential action of phytochemicals on platelet apoptosis: A biological overview. Curr. Med. Chem., 20 (8): 1018-27, 2013.

33- KUROSAWA T., HIROI H., MOMOEDA M., INOUE S. and TAKETANI Y.: Clomiphene citrate elicits estrogen agonistic/antagonistic effects differentially via estrogen receptors alpha and beta. Endocr. J., 57 (6): 517-21, 2010.

\section{تآثير الكروسين على تكيس المبايض المستحثة بالليتروزول}

$$
\text { الهدف من البحث: يهدف هذا البحث إلى دراسة تآثير الكروسين على تكيس المبايض المستحثه بالليترنفل. }
$$

طرق البحث: تم إجراء هذا البحث على علد (•ع) من إناث فئران التجارب قسموا إلى آربع مجموعات كل مجموعة تحتصى على عدد (.)

• المجموعة الآولى (الهجموعة الطبيعية الضابطة): هذه المجموعة تم حقنها بمحلول ملحى نصف مليتر عبر الفشاء البريتونى ونصف ملليتر محلول ملح عن طريق الفم يومياً لمدة (r) آسابيع.

• الدجموعة الثانية: مجموعة تم إعطاؤها عقار الليترونفل لمدة (1) يوم بجرعة (1 ملإيجرام الكل كيلوجرام) عن طريق آنبوب داخل المعدة. • المجموعه الثالثة: مجموعة تم إعطاؤها عقار الليترونفل بنفس الجراعة كما في المجموعة الثانية ثم عقار الكروسين بجرعة (.0 ملليجرام لكل كيلو جرام) يومياً لمدة (T) آسابيع عبر الغشاء البراء البريتونى.

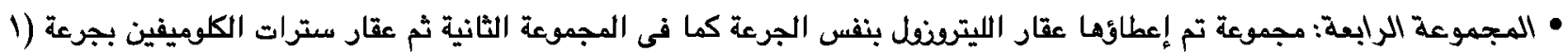

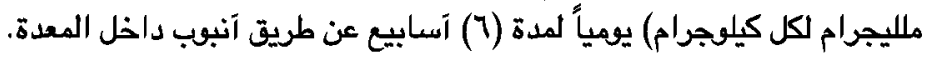

في نهاية التجرية، تم تخدير الحيوانات بواسطة إيثر ثنائى الإيثيل، ثم تم ذبح الحيوانات عن طريق قطع الرآس وتم قياس الهرموناتيات الآتيه:

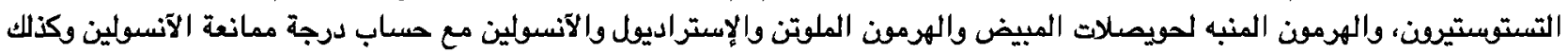

نسبة الكوليستيرول فى الدم. وعلاوة على ذلك تم فحص عينة من آنسجة المبيض من كل مجموعة.

$$
\text { النتائج: وقد دلت نتائج هذا البحث على الآتى: }
$$

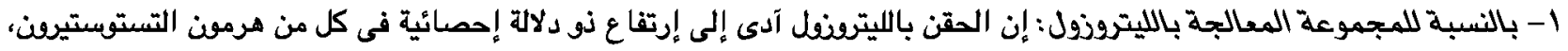

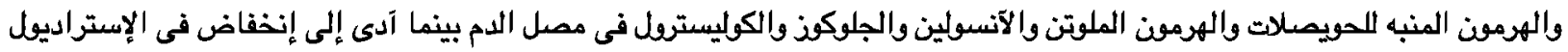

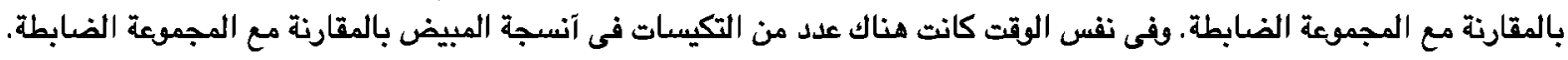

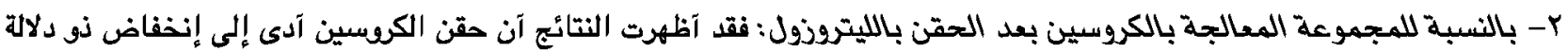

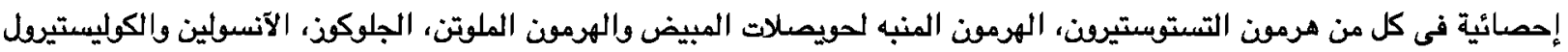

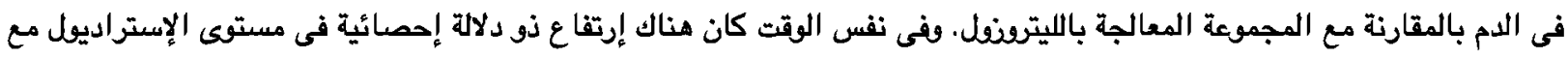

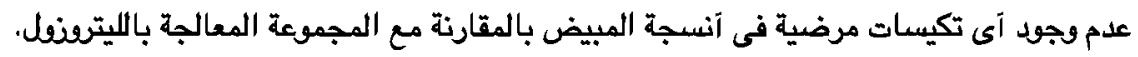
ب- بالنسبة للمجموعة المعالجة بسترات الكلومفين بعد الحقن بالليتروزول: آظهرت النتائج آن العلاج بسترات الكلومفين آدى إلى نتائج متطابقة مع المجموعة المعالجة بالكروسين.

الإستتاج:نستخلص من هذا البحث آن الكروسين يلعب دوراً فعالاً فى المقاومة ضد تكيس المبايض المستحثة بالليترنفل. 